\title{
Simulation of Stone Column Ground Improvement (Comparison between Axisymmetric and Plane Strain)
}

\author{
Maryam Gaber, Anuar Kasa, Norinah Abdul-Rahman and Jamal Alsharef \\ Department of Civil and Structural Engineering, \\ Faculty of Engineering and Built Environment, \\ Universiti Kebangsaan Malaysia, 43600 Bangi, Selangor, Malaysia
}

Article history

Received: 20-12-2017

Revised: 27-12-2017

Accepted: 15-01-2018

Corresponding Author: Maryam Gaber Department of Civil and Structural Engineering, Universiti Kebangsaan Malaysia, 43600 Bangi, Selangor, Malaysia Email:mm_gaber@yahoo.com

\begin{abstract}
Most of the numerical studies on stone columns are based on the unit cell concept. However, the impact of interactions between adjacent columns and between the columns and the surrounding soil has not been investigated thoroughly. In this study, the finite element software, PLAXIS-2D-V8.2, was used to simulate a stone column as a unit cell and as a plane strain model in order to specify the difference between the performances of each model. The key factors that were investigated included the diameter and c/c spacing of the stone columns, friction angle of the stone column material and undrained cohesion of the soft soil. The emphasis of this parametric study was on the settlement improvement factor and excess pore water pressure, since these are critical to the design of stone columns. The main findings of this study were that in the plane strain model, the settlement improvement factor ranged between 2.2 and 3.2, which means that the settlement was improved more than twice. Meanwhile, in the unit cell concept, the settlement improvement factor did not exceed 1.53. The results of the settlement improvement were compared with the theoretical solutions that are commonly used for studies into the behaviour of stone columns. The unit cell model showed a lower peak value of excess pore water pressure than the plane strain model.
\end{abstract}

Keywords: Stone Column, Unit Cell, Plane Strain, Settlements Improvement Factor, Excess Pore Water Pressure, Numerical Analysis

\section{Introduction}

Ground improvement techniques have been used in many difficult foundation sites throughout the world to increase the bearing capacity, reduce the settlement, improve the slope stability and also to resist liquefaction. Stone columns improve soft soils due to: (i) The inclusion of a firmer column material such as crushed stones in the soft soil; (ii) the densification of the surrounding soft soil during the installation of stone columns (Choobbasti et al., 2011); and (iii) the creation of a vertical drainage path by the stone columns (Guetif et al., 2007).

Several researchers developed related studies based on theories, experiments and field observations to evaluate the behaviour of stone columns (Greenwood, 1970; Priebe, 1976; Ambily and Gandhi, 2007; Malarvizhi and Ilamparuthi, 2007; Andreou et al., 2008; Lo et al., 2010; Al-Kaisi and Ali, 2013; Al-Saoudi et al.,
2014). They provided detailed results on the behaviour of a single column and a group of columns by varying parameters like the area replacement ratio, shear strength of the soft clay, columns stiffness, etc.

A complex modelling of the soil reinforcement system is needed to simulate and analyse stone column ground improvement. According to Dheerendra Babu et al. (2013), there are five main numerical approaches to the modelling of stone columns: (i) The axisymmetric model, which is a "unit cell" comprised of only one column and the surrounding soil (Balaam and Booker, 1981); (ii) the plane strain model, where the cylindrical columns are modelled as stone trenches, which are used extensively under long loads, such as embankments (Van Impe and De Beer, 1983); (iii) the axial symmetry technique, where stone rings are modelled instead of cylindrical columns in order to simulate the columns under circular loads such as tanks 
(Elshazly et al., 2008); (iv) the homogenization technique, which can be used to model the improved homogeneous soil with stone columns using the composite soil parameters (Jellali et al., 2005; Abdelkrim and Buhan, 2007); and (v) the full 3D model, which is the most complex approach to the stone column system (Weber et al., 2008).

Compared to an experimental investigation, the numerical analysis of stone columns is more flexible, as well as efficient in terms of cost and time. The understanding of this system has been greatly improved due to numerical studies. However, most of the numerical studies adopted the unit cell modelling method, while only a few adopted other approaches such as the plane strain and 3D models. In practice, the plane strain model has been used to simulate embankment projects on soft soil with a high groundwater level. The current study focused on the impact of the selected model on the behaviour of stone columns by a direct comparison between the unit cell and plane strain approaches.

The unit cell concept is commonly used to design and evaluate the performance of stone columns (Baumann and Bauer, 1974; Ng and Tan, 2014; Abhijit and Das, 2000). The unit cell model involves a single stone column with an equivalent circular zone of influence. The equivalent diameters of the stone columns for triangular, square and hexagonal patterns are 1.05, 1.13 and $1.29 \mathrm{~S}$, respectively, where $\mathrm{S}$ is the $\mathrm{c} / \mathrm{c}$ spacing of the columns (Balaam and Booker, 1981).

In the current paper, 2D finite element analysis was utilized to simulate a single as well as a group of endbearing stone columns embedded in soft clay soil below an embankment. In addition, the study focused on some factors that impacted both the Settlement Improvement Factor (SIF) and excess pore water pressure in the unit cell and plane strain models. Moreover, the study tried to fill the gap of knowledge about the difference between using the unit cell and plane strain approaches in numerical models and checked the accuracy of each through the results that were obtained.

\section{Geometry and Ground Conditions}

The selected problem in this study involved stone columns that supported a large embankment with 2:1 side slopes. A synopsis of this project that was relevant to the current study is described as follows: For the purpose of ground improvement, columns, with a diameter of $1 \mathrm{~m}$, were installed in a square grid with a $\mathrm{c} / \mathrm{c}$ spacing of $2 \mathrm{~m}$ between the columns. The $8 \mathrm{~m}$ long columns were fully penetrating and rested on a firm stratum to support a $10.5 \mathrm{~m}$ high embankment. The embankment was constructed in stages to allow partial dissipation of excess pore water pressure during construction. The construction of the embankment was modelled in two stages, where the duration and fill thickness of each stage are summarized in Table 1. In order to consider the long- term performance, the modelling was extended to 1000 days after the end of construction.

\section{Generation Modelling and Material Properties}

The construction and consolidation of the embankment on soft soil was simulated by two different constitutive models, the unit cell and plane strain model, using PLAXIS 2D, where the $2 \mathrm{D}$ and $3 \mathrm{D}$ models gave results that were similar to each other, especially on the settlement performance and the failure mechanism ( $\mathrm{Ng}$ and Tan, 2015). The 2D-axisymmetric model with 290 (15-node) triangular elements was built with an equivalent diameter, $\left(d_{e}=1.13 \mathrm{~S}\right)$. Meanwhile, in the plane strain analysis, the representative model consisted of 1189 (15-node) triangular elements. Due to the symmetry of both models, only half of the cross-section was simulated to save computing time. The phreatic level was set at $1 \mathrm{~m}$ below the top surface. Figure 1 shows the cross sections of the two models that were used in the analysis with a finite element mesh and boundary conditions. The lateral boundaries of the models were closed (impervious), while the drainage boundaries were assumed to be at the ground surface and at the bottom of model (the excess pore pressure at the nodes along the boundaries was set to zero).

After the generation of the initial stress and pore water pressure, the stone column was modelled by replacing the soft soil element. The Mohr-Coulomb failure criterion was adopted for all the material elements. The properties of the soft clay, stone column and sand for the modelling were taken from the case studies of Adnan (2014). A drained behaviour was assumed for the stone column and the fill material, whilst the soft clay was assumed to be undrained. The input parameters of the Mohr-Coulomb model involved the stiffness modulus (E), drained cohesion (c), internal friction angle $(\varphi)$, dilation angle $(\psi)$, Poisson's ratio (v) and unit weight $(\gamma)$. All these parameters and the interface strength between the stone column and soft clay $\left(\mathrm{R}_{\text {inter }}\right)$ are tabulated in Table 2 .

A consolidation analysis was selected to investigate the soft soil reinforced with ordinary stone columns. This type of analysis should be used to consider the dissipation of excess pore water pressure. Each modelling was divided into three major steps: (1) Initializing the stress field and hydrostatic pore water pressure distribution (after the construction of the last layer, the calculations were taken until the excess pore pressure had dissipated to a residual value of $1 \mathrm{kPa}$ to determine the final consolidation settlement); (2) building the embankment in stages; and (3) applying and maintaining the traffic load. The traffic load was simulated by applying a uniformly distributed load (20 $\mathrm{kPa}$ ) to the top of the embankment. 


\section{Parametric Study}

A parametric study was conducted to evaluate the behaviour of the stone columns by comparing between two different simulation and to investigate the influence of several key factors. A series of parametric analyses were performed, where each parameter was varied at a time while the other parameters were kept constant, as listed in Table 3.
Table 1: Construction sequences of embankment (Adnan, 2014)

\begin{tabular}{llc}
\hline Stage & Fill height $(\mathrm{m})$ & Time consumed (day) \\
\hline First & $0-1$ & 4.0 \\
& 3.0 & 7.0 \\
Second & 0.0 & 42.0 \\
& 3.5 & 3.5 \\
& 3.0 & 3.5 \\
& 0.0 & 1000.0 \\
\hline
\end{tabular}

Table 2: Soil data sets parameters used for validation of PLAXIS

\begin{tabular}{|c|c|c|c|c|c|c|}
\hline \multicolumn{2}{|c|}{$\begin{array}{l}\text { Mohr-Coulomb } \\
\text { Type }\end{array}$} & $\begin{array}{l}\text { Blanket layer } \\
\text { Drained }\end{array}$ & $\begin{array}{l}\text { Fill material } \\
\text { Drained }\end{array}$ & $\begin{array}{l}\text { Firm clay } \\
\text { Undrained }\end{array}$ & $\begin{array}{l}\text { Soft clay } \\
\text { Undrained }\end{array}$ & $\begin{array}{l}\text { Stone column } \\
\text { Drained }\end{array}$ \\
\hline$\gamma_{\text {unsat }}$ & {$\left[\mathrm{kN} / \mathrm{m}^{3}\right]$} & 19 & 17 & 16 & 15 & 12 \\
\hline$\gamma_{\text {sat }}$ & {$\left[\mathrm{kN} / \mathrm{m}^{3}\right]$} & 22 & 18 & 17 & 16 & 22 \\
\hline $\mathrm{k}_{\mathrm{x}}$ & {$[\mathrm{m} / \mathrm{day}]$} & 1 & 1 & $7.36 * 10^{-5}$ & $7.36 * 10^{-5}$ & 1 \\
\hline $\mathrm{k}_{\mathrm{y}}$ & {$[\mathrm{m} / \mathrm{day}]$} & 1 & 1 & $3.68 * 10^{-5}$ & $3.68 * 10^{-5}$ & 0.5 \\
\hline $\mathrm{E}_{\text {ref }}$ & {$\left[\mathrm{kN} / \mathrm{m}^{2}\right]$} & $20 * 10^{3}$ & $20 * 10^{3}$ & $15^{*} 10^{3}$ & $2 * 10^{3}$ & $20 * 10^{3}$ \\
\hline $\mathrm{v}$ & {$[-]$} & 0.333 & 0.333 & 0.4 & 0.4 & 0.333 \\
\hline$c_{\text {ref }}$ & {$\left[\mathrm{kN} / \mathrm{m}^{2}\right]$} & 0.1 & 0.1 & 23 & 28 & 0.1 \\
\hline$\varphi$ & {$\left[^{\circ}\right]$} & 35 & 30 & 28 & 1 & 38 \\
\hline$\psi$ & {$\left[{ }^{\circ}\right]$} & 0 & 0 & 0 & 0 & 8 \\
\hline $\mathrm{R}_{\text {inter. }}$ & {$[-]$} & - & - & - & 1 & 1 \\
\hline
\end{tabular}

Table 3: Range of parameters

\begin{tabular}{lll}
\hline Parameter & Unit & Value range \\
\hline c/c spacing ratio $(\mathrm{S} / \mathrm{d})$ & {$[-]$} & $2,2.6,3$ and 3.4 \\
Diameter ratio $(\mathrm{d} / \mathrm{S})$ & {$[-]$} & $0.4,0.45,0.5,0.55$ and 0.6 \\
Internal friction angle $(\varphi)$ & {$\left[{ }^{\circ}\right]$} & $30,38,40$ and 45 \\
Undrianed cohesion $(\mathrm{c})$ & {$[\mathrm{kPa}]$} & $15,20,28,30$ and 35 \\
\hline
\end{tabular}

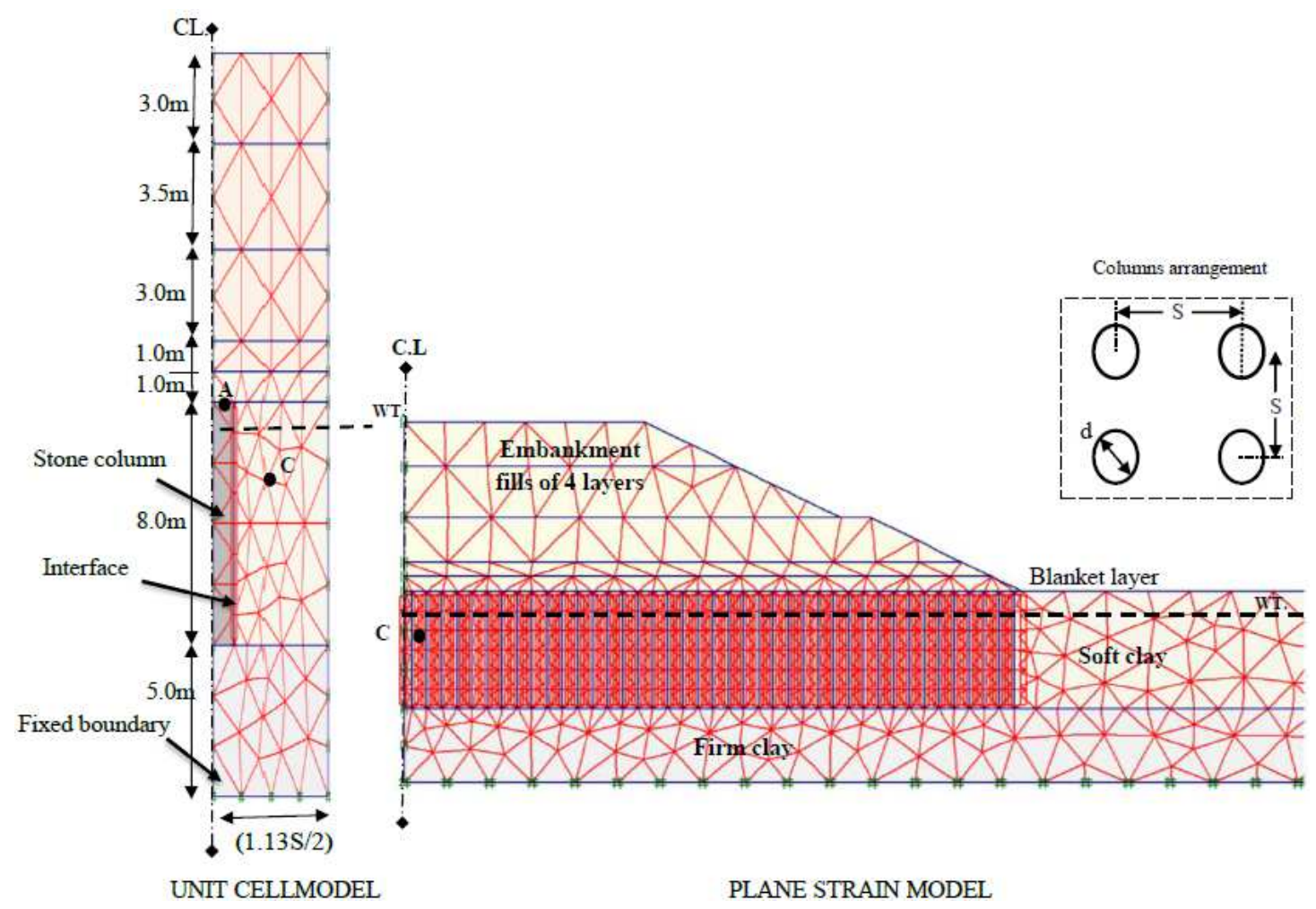

Fig. 1: Site cross section with geometric characteristics and mesh of embankment project modeled using axisymmetric and plane strain conditions 


\section{Results and Discussion}

\section{Settlement Improvement Factor}

The deformation behaviour is one of the factors that are taken into account when designing stone columns to support roadways, railways, etc. Most investigators focus on the settlement at the base of the embankment since the maximum long-term settlement occurs at this elevation (Huang and Han, 2010). Moreover, the settlement performance is expressed as the settlement improvement factor SIF, which is defined as:

$$
S I F=\frac{S_{u}}{S_{t}}
$$

Where:

$$
S_{u} \text { (untreated) }=\text { The settlement without stone column }
$$
treatment

$S_{t}$ (treated) = Corresponds to the settlement with stone column treatment

The SIF in this study was measured at the end of the second stage of construction in order to consider the long-term conditions (during serviceability) at the reference point (A) (Fig. 1). The change in the SIF was given in terms of the changes to all the parameters mentioned in Table 3.

The c/c spacing between adjacent columns is one of the important design parameters in this system, where it is directly related to the area replacement ratio of the columns (e.g., larger spacing of columns lead to a smaller area replacement ratio). Figure $2 \mathrm{a}$ indicates that in both the models that were used there was a gradual decrease in the SIF as the spacing ratio (S/d) increased. The SIF decreased by 25.9 and $22 \%$ when the spacing ratios were increased from 2 to 3.4 in the plane strain and unit cell models, respectively. The maximum values of the factor were 2.832 and 1.302 according to plane strain and unit cell models, respectively. These results were expected since the unit cell model does not consider the interactions between adjacent columns and between the column and the surrounding soil, which enhance the system resistance and reduce deformation. According to the unit cell results, the settlement of the reinforced ground did not improve much compared to the unimproved ground when the $\mathrm{c} / \mathrm{c}$ spacing was greater than three times its diameter. Bergado et al. (1990) concluded the same observation in their study when the c/c spacing was greater than four times the diameter of the column.

Figure $2 \mathrm{~b}$ shows the results of the investigation into the effect of the column diameter ratio $(\mathrm{d} / \mathrm{S})$ on the SIF obtained from the use of both approaches. The results indicated that the higher value of the stone column diameter was followed by a gradual increase in the SIF. Generally, using stone columns to reinforce the soil will lead to a reduction in the settlement and an achievement of about 1.52 and 3.28 times the settlement improvement when the unit cell and plane strain are used, respectively. Both the models that were used showed the same behaviour with the same rate of improvement, where an increase of 37.1 and $36 \%$ in the SIF resulted from the plane strain and unit cell models, respectively when the $d / S$ was increased from 0.4 to 0.6 .

As can be seen in Fig. 2c, the results of the SIF investigation illustrated that better quality stone column material yielded a higher SIF for the embankment system. The increasing effect was more significant in the plane strain model than in the unit cell model. According to the analysis of the unit cell concept, almost constant SIF values were obtained for $\varphi \geq 38^{\circ}$, i.e., for stone columns where $\varphi=38^{\circ}$ and $45^{\circ}$, the SIF improved by $2.4 \%$ only. The result of the current study was in agreement with $\mathrm{Ng}$ (2017), who stated that the friction angle of the column material has a moderate influence on the settlement ratio.

The settlement improvement factor decreased slightly as the undrained cohesion of soft soil increased, as shown in Fig. 2d. The SIF reached a constant value as the undrained cohesion of soil increased to more than 28 $\mathrm{kPa}$, where there was no significant difference in the SIF behaviour between both approaches. For the soil with an undrained cohesion that was equal to or more than 28 $\mathrm{kPa}$, the SIF was almost constant, with an average value of 1.09 and 2.833 in the unit cell and plane strain models, respectively. From this numerical study, it was observed that the use of stone columns for soil with a low undrained cohesion had a greater effect on the settlement. Moreover, the undrained cohesion of the soft clay became less significant as the cohesion was higher than $28 \mathrm{kPa}$ and this result was in agreement with the study by Abusharar and Han (2011), when they investigated the 2D deep-seated slope stability of embankments over stone columns. They concluded that the undrained cohesion of the soft clay became less significant as the cohesion was higher than $25 \mathrm{kPa}$.

\section{Differential Settlement}

The differential settlement between the column and the surrounding soil for this system was clearer in the plane strain than in the unit cell model, as indicated in Fig. 3 and 4. At a selected section [A-A], the plane strain analysis showed a variable settlement that was between the minimum and maximum value of 144.9 to 186.27 $\mathrm{mm}$ along the embankment base. Besides, the unit cell model showed a less variable settlement at the same section, where the settlement varied between 196.5 and $203.5 \mathrm{~mm}$ for the same test case. 


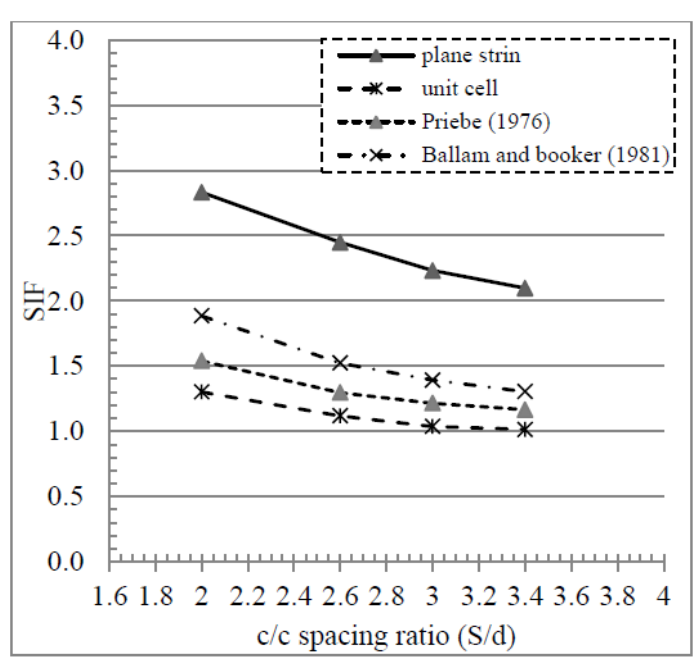

(a)

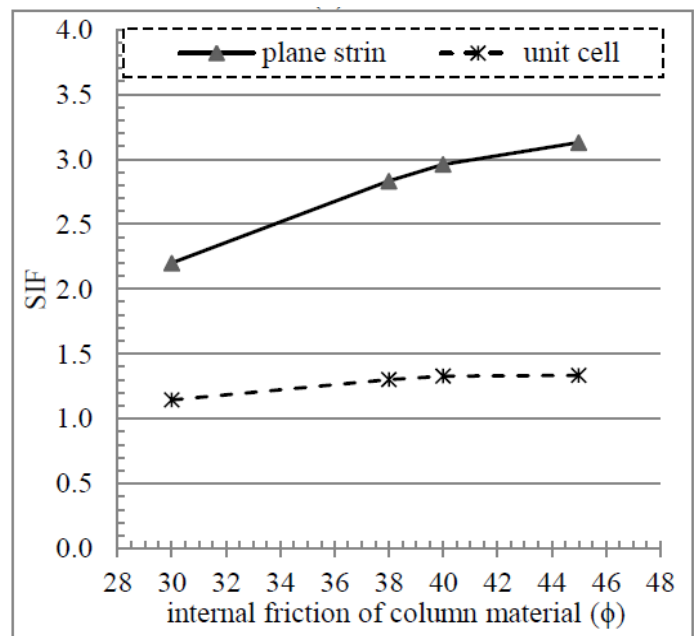

(c)

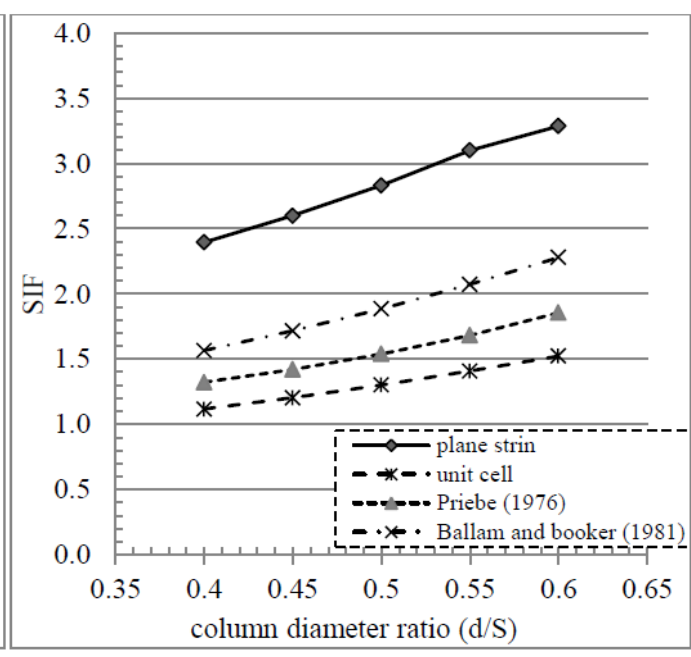

(b)

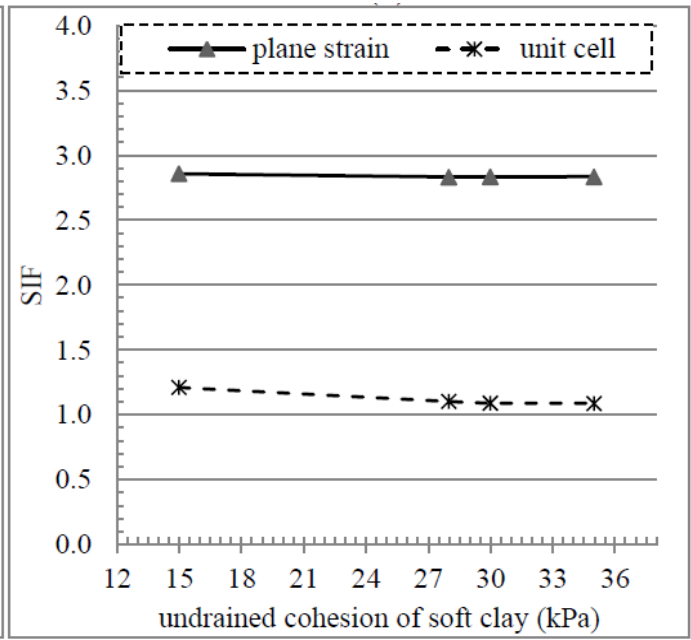

(d)

Fig. 2: Factors influencing SIF: (a) c/c spacing ratio (S/d); (b) stone column diameter ratio (d/S); (c) friction angle of stone column material; (d) undrained cohesion of soft clay
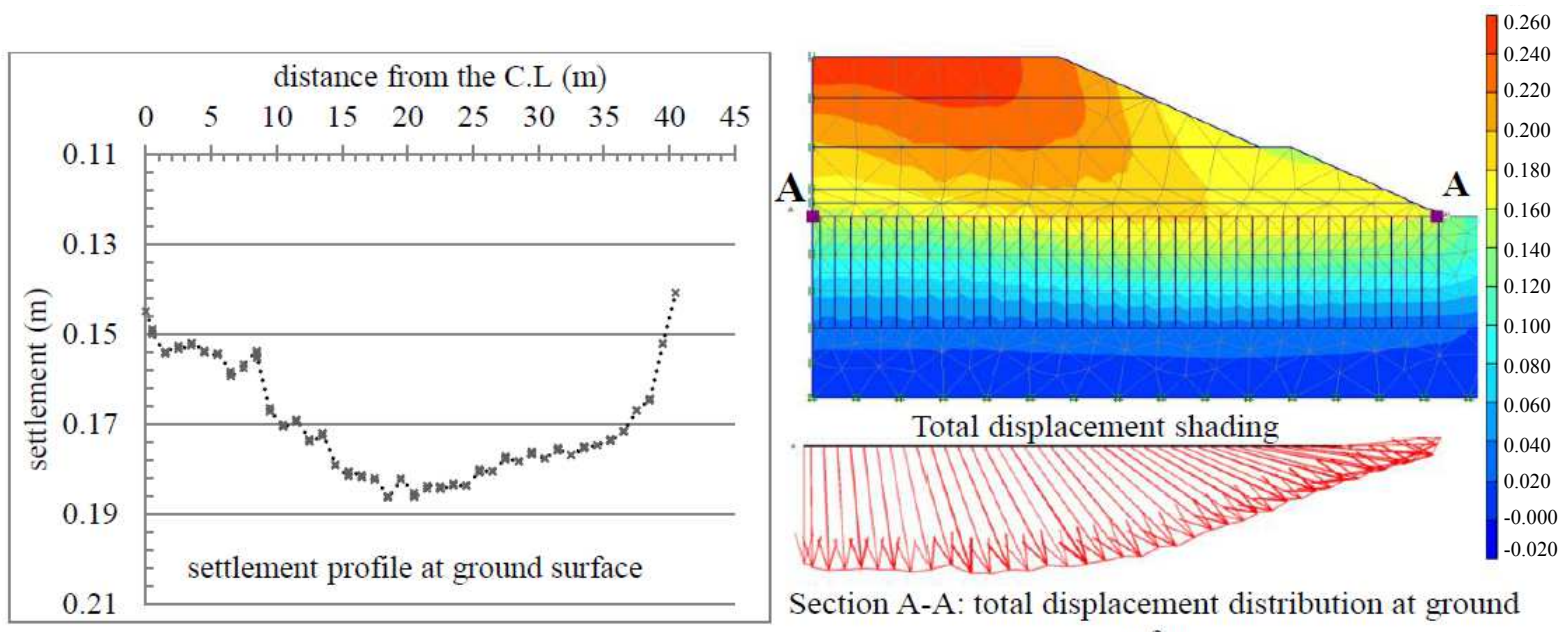

Section A-A: total displacement distribution at ground surface

Fig. 3: Total displacement distribution with differential settlement calculated at GL (plane strain model) 

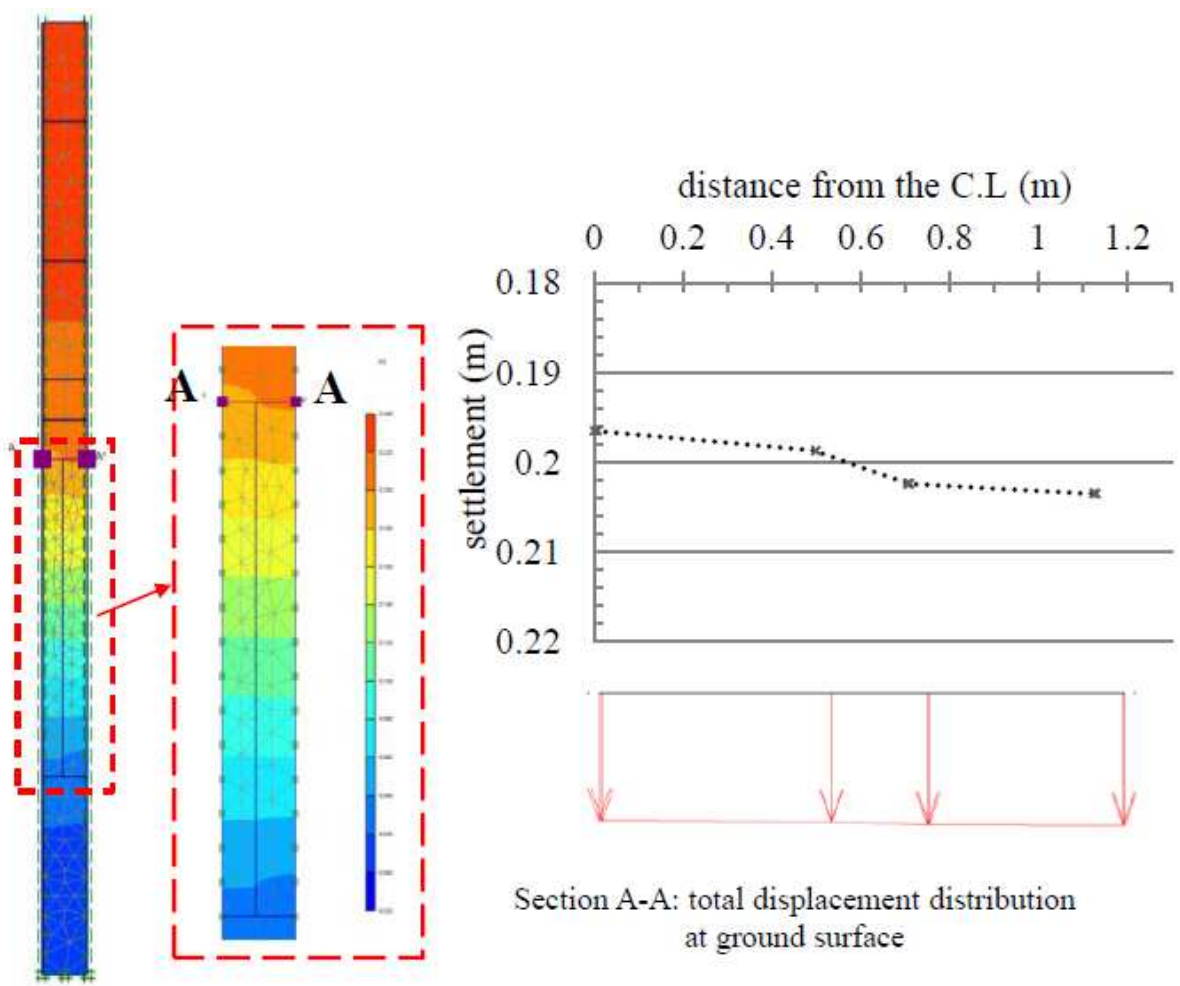

Total displacement shading

Fig. 4: Total displacement distribution with differential settlement calculated at GL (unit cell model)

\section{Validation of the Results}

The Priebe method has been used widely for stone column ground improvement projects. Priebe (1976) and Balaam and Booker (1981) came up with the computation for the settlement of a stone column. As can be seen in Fig. $2 a$ and $2 b$, the analytical methods indicated similar behaviour with the FEM results. However, the plane strain calculation tends to overestimate the SIF comparing with the Priebe and Ballam methods meanwhile, the derived SIF based on the unit cell model were much close to theoretical used methods. This result is expected since both of Priebe and Ballam methods were derived based on unit cell concept. Unfortunately, both Priebe and Ballam did not consider all the parameters in this part of the study such as the undrained cohesion of soft clay. In order to judge the results of the numerical analysis, a comparison was made with the results of some case histories, as summarized in Table 4.

\section{Excess Pore Water Pressure}

Stone columns can significantly accelerate the rate of consolidation of soft clays due to the following two mechanisms: (i) High column permeability, which causes radial drainage resulting in faster dissipation of excess pore water pressure; and (ii) high column stiffness, which leads to reduced vertical stress on the soil body, thereby reducing the generation of excess pore water pressure.

In this study, the two approaches that were used to simulate the stone column behaviour resulted in different excess pore pressure values at the reference point (C) (located $2 \mathrm{~m}$ below the water table level (Fig. 1)) for all the tested models as this factor requires more attention during the design stage. Generally, at the beginning of each stage of construction, the dissipation of the excess pore water pressure increased suddenly due to an increase in the embankment loading and each sudden increase was followed by a gradual decrease.

Figure 5a shows the simulated excess pore water pressure with time when $\mathrm{S} / \mathrm{d}=2$. The excess water pressure had peak values of approximately 24.3 and 3.87 $\mathrm{kPa}$ due to the embankment construction and then dissipated at different rates to nearly zero after 90 days for the plane strain and unit cell models, respectively. This fast dissipation resulted from the drainage and stress transfer from the soil to the columns, as noted by Han and Ye (2001) when they studied the consolidation of the soft soil treated with stone columns.

Figure $5 \mathrm{~b}$ indicates the difference between the results of the excess pore pressure when a stone column with a diameter of $0.6 \mathrm{~S}$ was used. There was 
a clear difference in the peak value of the excess pressure and dissipation time. Moreover, the residual excess pore water pressure was less than $1 \mathrm{kPa}$ when $\mathrm{d} / \mathrm{S}=0.6$ at approximately 66 and 110 days based on the unit cell and plane strain models, respectively from the start of construction.

Table 4: Case histories and comparison of SIF

\begin{tabular}{lllrl}
\hline Reference: & Material treated & $\mathrm{d}_{(\text {avg })} / \mathrm{S}$ & $\mathrm{H}_{\text {avg. }}(\mathrm{m})$ & SIF \\
\hline Castelli et al. (1983) & Clay & 0.524 & 18.00 & 3.400 \\
Cooper and Rose (1999) & Clay & 0.401 & 4.35 & 2.550 \\
Greenwood (1970) & Clay, peat & 0.522 & 6.00 & 1.630 \\
Venmans (1998) & Clay & 0.433 & 5.20 & 1.540 \\
Raju (1997) & Clay & 0.500 & 15.00 & 2.500 \\
Current study (plane strain) & Soft clay & 0.400 & 8.00 & 2.396 \\
& & 0.500 & & 2.832 \\
Current study (unit cell) & Soft clay & 0.400 & 8.00 & 1.117 \\
& & 0.500 & & 1.302 \\
\hline
\end{tabular}
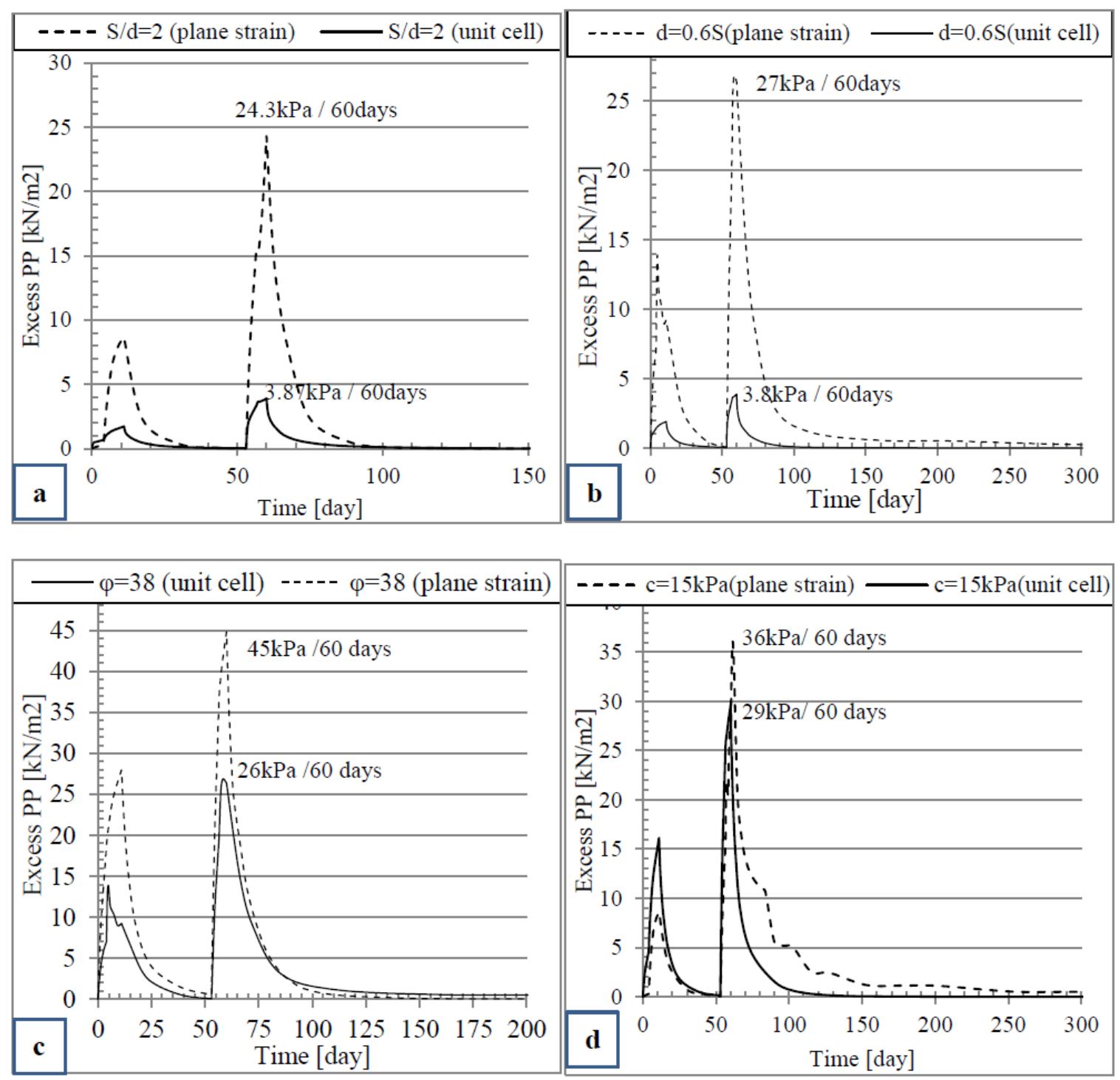

Fig. 5:Compression between unit cell and plane strain models factors influencing excess pore water pressure-time curves: (a) c/c spacing ratio $(\mathrm{S} / \mathrm{d})$; (b) stone column diameter ratio $(\mathrm{d} / \mathrm{S})$; (c) friction angle of stone column material; (d) undrained cohesion of soft clay 
When the column had a friction angle of $38^{\circ}$, the results of the excess pore water pressure with time were plotted as in Fig. 5c in order to make a comparison between the two models that were used in this study. As usual, the graph of the excess pore pressure indicated that the plane strain model resulted in higher pressure than the unit cell model. The difference between the excess pore water pressure of the soft soil at $15 \mathrm{kPa}$ became less significant in the undrained cohesion state and was about $5 \mathrm{kPa}$ after 60 days (Fig. 5d). The peak values of the excess pore pressure for the plane strain model were higher than those of the unit cell model in relation to the measured points and the impact of the columns and the soil interaction.

\section{Conclusion}

The current paper presented a comparison between two different approaches to the simulation of stone columns and investigated their performance by means of a numerical analysis. The Settlement Improvement Factor (SIF) and excess pore water pressure were investigated. The following conclusions were made:

- In all the series of models used in this study, when the stone column system was modelled on the unit cell concept the SIF was found to be smaller than when the plane strain model was used. This result was expected due to the effect of the interference and friction of the column with the surrounding soil in the plane strain system

- Among the different models, the stone column with a bigger diameter ratio, lower spacing ratio and higher friction angle indicated better behaviour against the settlement and dissipation of water pressure

- Since the excess pore water pressure was greatly affected by the model of analysis, the designer has to be careful when analysing and designing projects with higher ground water levels

- Finally, the authors of this paper advise the researchers and the designers to select the correct way to simulate the problem

\section{Acknowledgment}

The authors gratefully acknowledge the financial support provided by Reinforced Fire-Proof Concrete Tunnel Lining - Universiti Kabangsaan Malaysia UKM under research grant DIP-2014-019 in this work.

\section{Author's Contributions}

Maryam Gaber: Collection of data, modelling and simulation, analysis and interpretaion of the results, drafting and reviewing of the manuscript.
Ir. Dr. Anuar Kasa: Is the supervisor and coordinator of the research. He participated in the conceptualisation, coordination and designing of the research,contributed to the the analysis and interpretation of results.

Dr. Norinah Abdul-Rahman: Is the co-supervisor of the research. She participated in the conceptualisation and designing of the research,contributed to the analysis and interpretation of results.

Mr. Jamal Alsharef: He participated in the modelling and simulation, analysis and interpretaion of the results, drafting of the manuscript.

\section{Ethics}

The current article is original and contains unpublished material. The corresponding author confirms that all of the other authors have read and approved this manuscript and there are no ethical issues involved.

\section{References}

Abdelkrim, M. and P.D. Buhan, 2007. An elastoplastic homogenization procedure for predicting the settlement of a foundation on a soil reinforced by columns. Eur. J. Mechan. A/Solids, 26: 736-757. DOI: $10.1016 /$ j.euromechsol.2006.12.004

Abhijit, S. and S.C. Das, 2000. Interaction analysis of stone column groups in foundations. Proceedings of the Indian Geotechnical Conference, (IGC' 00), Bombay, India, pp: 279-284.

Abusharar, S.W. and J. Han, 2011. Two-dimensional deep-seated slope stability analysis of embankments over stone column-improved soft clay. Eng. Geol., 120: 103-110. DOI: 10.1016/j.enggeo.2011.04.002

Adnan, Q., 2014. Behavior of stone column embedded in soft clays under embankment by using finite element and artificial intelligent methods. PhD Thesis, Universiti Kebangsaan Malaysia.

Al-Kaisi, A.A.R. and H.H. Ali, 2013. Mathematical estimation for the bearing capacity of sand column inserted in soft clay soil. Eng. Technol. J., 31: 816-827.

Al-Saoudi, N.K.S., M.M.M. Al-Kaissi and N.A.A. Rajab, 2014. Treatment of soft soil by sand columns. Eng. Technol. J., 32: 2106-2118.

Ambily, A.P. and S.R. Gandhi, 2007. Behavior of stone columns based on experimental and FEM analysis. ASCE, J. Geotech. Geoenviron. Eng., 133: 405-415. DOI: 10.1061/(ASCE)1090-0241(2007)133:4(405)

Andreou, P., W. Frikha, J. Canou, V. Papadopoulos and J.C. Dupla, 2008. Experimental study on sand and gravel columns in clay. Proc. ICE-Ground Improvement, 161: 189-198.

DOI: 10.1680 /grim.2008.161.4.189 
Balaam, N.P. and I.R. Booker, 1981. Analysis of rigid rafts supported by granular piles. Int. J. Numerical Analytical Meth. Geomechan., 5: 379-403. DOI: $10.1002 /$ nag. 1610050405

Baumann, V. and G.E.A. Bauer, 1974. The performance of foundations on various soils stabilized by the vibro-compaction method. Can. Geotech. J., 11: 509-530. DOI: $10.1139 / \mathrm{t} 74-056$

Bergado, D.T., N. Singh, S.H. Sim, B. Panichayatum and C.L. Sampaco et al., 1990. Improvement of soft Bangkok clay using vertical geotextile band drains compared with granular piles. Geotext. Geomembr., 9: 203-231. DOI: 10.1016/0266-1144(90)90054-G

Castelli, R.J., S.K. Sarkar and G.A. Munkfakh, 1983. Ground treatment in the design and construction of a wharf structure. Proceedings of the International Conference on Advances in Piling and Ground Treatment for Foundations, (GTF' 83), Institution of Civil Engineers, London, pp: 275-281.

Choobbasti, A.J., A. Zamatkesh and R. Noorzad, 2011. Performance of stone columns in soft clay: Numerical evaluation. J. Geotech. Geol. Eng., 29: 675-684. DOI: 10.1007/s10706-011-9409-x

Cooper, M.R. and A.N. Rose, 1999. Stone column support for an embankment on deep alluvial soils. Proc. Instit. Civil Eng. Geotech. Eng., 137: 15-25. DOI: $10.1680 /$ gt.1999.370103

Dheerendra Babu, M.R., S. Nayak and R. Shivashankar, 2013. A critical review of construction, analysis and behaviour of stone columns. J. Geotech. Geol. Eng., 31: 1-22. DOI: 10.1007/s10706-012-9555-9

Elshazly, H.A., D.A. Hafez and M.E. Mossaad, 2008. Reliability of conventional settlement evaluation for circular foundations on stone columns. J. Geotech. Geol. Eng., 26: 323-334.

DOI: $10.1007 / \mathrm{s} 10706-007-9169-9$

Greenwood, D.A., 1970. Mechanical improvement of soils below ground surfaces. Proceedings of the Ground Engineering Conference, (GEC' 70), Institution of Civil Engineers, London, pp: 11-22.

Guetif, Z., M. Bouassida and J.M. Debats, 2007. Improved soft clay characteristics due to stone column installation. J. Comput. Geotech., 34: 104-111. DOI: 10.1016/j.compgeo.2006.09.008

Han, J. and S.L. Ye, 2001. Simplified method for consolidation rate of stone column reinforced foundations. J. Geotech. Geoenviron. Eng., 127: 597-603.

DOI: 10.1061/(ASCE)1090-0241(2001)127:7(597)

Huang, J. and J. Han, 2010. Two-dimensional parametric study of geosynthetic-reinforced column-supported embankments by coupled hydraulic and mechanical modeling. J. Comput. Geotech., 37: 638-648.

DOI: 10.1016/j.compgeo.2010.04.002
Jellali, B., M. Bouassida and P.D. Buhan, 2005. A homogenization method for estimating the bearing capacity of soils reinforced by columns. Int. J. Numerical Analytical Meth. Geomech., 29: 989-1004. DOI: 10.1002/nag.441

Lo, S.R., R. Zhang and J. Mak, 2010. Geosyntheticencased stone columns in soft clay: A numerical study. Geotextiles Geomembranes, 28: 292-302. DOI: 10.1016/j.geotexmem.2009.09.015

Malarvizhi, S.N. and Ilamparuthi, 2007. Comparative study on the behavior of encased stone column and conventional stone column. J. Soils Foundat., 47: 873-885. DOI: $10.3208 /$ sandf. 47.873

$\mathrm{Ng}$, K.S. and S.A. Tan, 2014. Design and analyses of floating stone columns. J. Soils Foundat., 54: 478-487. DOI: 10.1016/j.sandf.2014.04.013

$\mathrm{Ng}$, K.S. and S.A. Tan, 2015. Simplified homogenization method in stone column designs. J. Soils Foundat., 55: 154-165. DOI: 10.1016/j.sandf.2014.12.012

$\mathrm{Ng}$, K.S., 2017. Settlement ratio of floating stone columns for small and large loaded areas. J. GeoEng., 12: 89-96. DOI: 10.6310/jog.2017.12(2).5

Priebe, H., 1976. Evaluation of the settlement reduction of a foundation improved by Vibro Replacement. Die Bautechnik, 53: 160-162.

Raju, V.R., 1997. The Behaviour of Very Soft Soils Improved by Vibro-Replacement. In Ground Improvement Geosystems: Densification and Reinforcement, Davies, M.C.R. and F. Schlosser (Eds.), Thomas Telford, London, ISBN-10: 0727726056, pp: 253-259.

Van Impe, W.Y. and E. De Beer, 1983. Improvement of settlement behavior of softy layers by means of stone columns. Proceedings of the 8th International Conference on SMFE, (SMFE' 83), Helsinki, pp: 309-312.

Venmans, A.A.J., 1998. Design, construction and lifetime behaviour on a highway widening on stone column improved ground. Proceedings of the International Symposium on Problematic Soils, (SPS'98), Tohoku, pp: 105-108.

Weber, T.M., S.M. Springman, M. Gab, V. Racansky and H.F. Schweiger, 2008. Numerical Modelling of Stone Columns in Soft Clay Under an Embankment. In: Geotechnics of Soft Soils-Focus on Ground Improvement, Karstunen, M. and M. Leoni (Eds.), Taylor and Francis, London, pp: 305-311. 